\title{
MODERNIZATION OF EDUCATIONAL PRACTICES IN PEDAGOGICAL UNIVERSITIES
}

\author{
Hanna Trotsko \\ EdD, Professor, Corresponding Member of the \\ National Academy of Pedagogical Sciences of Ukraine \\ Vice-Rector for Academic Affairs \\ Kharkiv National Pedagogical University named after G. S. Skovoroda \\ 2 Valentinovskaya Str., 61000 Kharkiv, Ukraine \\ peduniversity@ukr.net
}

\section{ABSTRACT}

In the article are considered transformations of educational practices holding in pedagogical universities taking into account modern mobile sociocultural process. It is proved that moral senses of university idea realize society transformation potential of education thanking to involving to the system of studying and educational practices. Societal self-representation of pedagogical education is possible only because of humanized strategy of society modernization which expects wide involving of pedagogical ideas, norms, values into life world of society and person. Education in the spirit of piece, interconnection of moral and law education are important compounds of political education. One of the most important tasks of educational work should become world outlook culture forming of responsible pedagogue able to self-knowing, self-development, self-education.

Pedagogical science and education which substantiates meaning of cultural and moral factors must act not as an object but as a subject of social order. Educational practices holding in pedagogical university must be based on moral senses of university idea.

Key words: education; modernization; pedagogical university; educational practices; pedagogical communication; freedom; dignity; pedagogical ethics; Skovoroda tradition; nation patriotic education; pedagogy of peace.

\section{INTRODUCTION}

The processes of pedagogy of social relations in the era of global transformations are a challenge for pedagogical education. After all, it must respond effectively to and even ahead of time requests, be a powerful impetus for social update mechanisms both locally and globally. The study of the educational potential of higher pedagogical education is especially important for the spiritual renewal of Ukraine and the optimization of the educational process in Ukrainian universities. In recent years, more and more loud, there are suggestions on the need for systematic educational work with students who are mature and do not need paternalistic care from the academic community. But, as will be shown below, this is not quite as it may seem at first glance.

Despite the large number of studies devoted to the idea and reality of the university, the moral component of educational practices is perceived as an obvious, requiring not so much theoretical reflection, but the justification of the conditions for its implementation. But the very theoretical reflection of moral ideas, norms and values that act as regulators of educational practices, allows, on the one hand, to make a distinction between the moral-educational complex of the idea 
of a university of pedagogy and reality, and on the other - to identify the main directions of transformation practices of educational work.

The philosophical and anthropological substantiation of modernization transformations in modern culture, in conjunction with the formulation of educational tasks, is given in the writings of V. Kremen, M. Kultayeva, S. Kutsepal, G. Lyubbe, S. Proleeva, N. Radionova, M. Trinyak, P. Sloterdijka, V. Tabachkovsky.

The qualitative change in the ways of organizing educational and educational activities in the context of modern social transformations is analyzed in the studies of V. Grinev, L. Kalashnikova, S. Zolotukhina, V. Lozova, T. Rogova, L. Rybalko, A. Trotsko.

The purpose of the article: to find out the bases and main directions of transformation of practice of educational work in pedagogical universities taking into account the changing changing sociocultural contexts and to reveal the role of the teacher in the processes of social modernization.

\section{MODERNIZATION OF EDUCATIONAL PRACTICES}

Before modern education, an important task is to create in the younger generation a set of personal qualities of character, the most important human feelings that would motivate a person to positive actions and actions of a citizen (Kalashnikova, 2014, p. 125). These tasks were reflected in the National Strategy for the Development of Education of Ukraine for the period up to 2021, the Concept of National-Patriotic Education of Youth, the Laws of Ukraine "On Higher Education”, "On Protection of Public Morality”, etc.

In order to secure a social order for a modern school, the future teacher needs not only to acquire knowledge, methods and methods of educational work, but also to be a good citizen of his state with well-defined moral priorities. Pedagogical education as a component of the educational universe has always been supersituational, producing value priorities and moral norms of society. Therefore, in an era of qualitatively new socio-cultural meanings, pedagogical science and education, which justifies the importance of cultural and moral factors, must act not only as an object but also as a subject of social order. Through the system of university educational and educational practices that are dialectically interconnected, objectified, embodied in the educational and social life of the moral and humanistic complex of the idea of the university, which includes the idea of freedom, dignity, truth as the highest good and devotional service to man And homeland, justice, responsibility. According to M. D. Kultayev (2005), modernization transformations of educational work in accordance with modern socio-cultural requirements and university life in general require the preservation of the moral constancy of the metaphysical idea of the pedagogical university (p. 47-48).

The metaphysical aspect of the concept of Bildung (German education, culture, and formation), becoming the basis of the idea of the university, gives the latter a universal character. His central intention - freedom, free formation of man and humanity latently complemented by moral meanings (Kultaieva, 2005, p. 49). Thanks to the practices of world-view, national-patriotic, political education at universities, the historical memory of societies is intensified. Thus, in the communicative space of the oldest higher educational institution of Ukraine, Kharkiv National Pedagogical University named after. G. S. Skovoroda, the 
living ethics of the great Ukrainian philosopher and teacher Skovoroda created a unique atmosphere conducive to the deployment of various forms of educational and educational activities of humanistic orientation. The phenomenon of Skovoroda is a powerful source of pedagogical inspiration not only in educational institutions, but also in the world of life. "Honorary title of skovorodinivtsa - as I. F. Prokopenko - has an existential meaning, because living in Skovoroda means choosing the difficult path of responsible independence and service not only to abstract humanity, but also to concrete people ... The skovorodnik is already in its definition to be an enlightener, the Teacher in the high sense of the word. Educational institutions, especially pedagogical universities, carry out the mission of the continuation and development of Skovorodin's tradition" (Prokopenko, 2014, p. 5). For future teachers, an existential meeting with Skovoroda can take place in the form of a transistorphilosophical-educational dialogue (publication of scientific articles, participation of students in scientific congresses, lectures, round tables, events of artistic and artistic orientation), as well as in the field of pedagogical practice and pedagogical act ( Local lore and cultural and educational work among students and pupils; participation in "Young Leader's School", student activist camp "Skovorodinov's Family Leader" a volunteer project SkovorodaFest).

The Pedagogical University through self-examination and self-control, sets itself guidelines for the further development of the practice of educational work and constantly adjusts them taking into account the relevant situations. Practicing educational work involves the inexhaustible potential of self-renewal, for the implementation of which need pedagogical rationality. Pedagogical ethics in its didactic transformation is expressed in the anthropological and cultural, historical meanings embodied in it through the practices of ideological, national-patriotic, spiritual and moral education. In societies at risk, which are modern societies, the participation of pedagogical ethics in the design of social reality does not decrease, but increases. Thus, in the context of the open war with Russia and the threats of the new world war, the effectiveness of the ideas and practices of Cossack pedagogy is evident. In Kharkiv National Pedagogical University named after. G. S. Skovoroda from the very first years of independence paid considerable attention to the revival of the Cossack-Knights tradition (Prokopenko, 2003). Note to realworld universities teaching moral ideas, principles and guidelines, organizing and structuring educational work require specifying Based anthropological constants and variables available and hidden cultural and historical meanings. As a translator of humanistic national meanings and post-conventional values in the area of modern education, Cossack pedagogy has several modes: Cossack pedagogy as a didactic project (courses of Christian ethics as ethics of responsibility and critical thinking), Cossack pedagogy in military patriotic education (preparation for mastering military professions, formation willingness to serve in the army, protecting the homeland), Cossack education in national education (post-conventional values Cossack pedagogy used in the education of the individual, means teaching ethics humanist selection carried out ethnic and cultural traditions and meanings Cossack pedagogy). With 2002 at the University was established by the Institute of Ukrainian Cossacks and separate scientific and educational center of the Ukrainian Cossacks G. S. Scovoroda. By means of scientific and educational center specifically educated post-conventional patriotism skovorodynivtsya, based on democratic principles and values, awareness of personal responsibility to protect the borders of the state, its sovereignty and territorial integrity. 
Undoubtedly, we are experiencing an era of radical reappraisal of all values and the production of qualitatively new socio-cultural meanings that touch upon the underlying foundations of human existence. The upbringing crisis is manifested in such phenomena as dehumanization, disorientation, disharmony of a person and its life world. The risks of the emergence of repressive elements in pedagogical universities in educational practices are exacerbated by the fact that the educational system of Ukrainian universities has not yet completely eliminated the Soviet legacy of totalitarianism. As it is known, during the Soviet period, the moral universal human and national-cultural meanings of the ideas of the university almost did not affect the humanization of practices of educational work, which hindered the emergence of creative initiatives of youth, self-development of personality.

Today, the process of rationalization and ideas konkretyzatsiy University is influenced not so much ideology as a philosophy that sets ideals for conversion of real universities in ideological culture media and fair community postconventional morality. New prospects for self-identity in a positive mode of dignity open philosophical and pedagogical and philosophical and political intelligence P. Sloterdijk (Kultaieva, 2016a, p. 110-111). Speaking of social and cultural dezoriyentyry that from time to time produces School, P. Sloterdijk, in contrast to the modern theories deshkolyaryzatsiyi, said the institution evolutionary achievement of mankind and directs his criticism against the destruction of the anthropological foundation of educational practices. Philosopher observes at the outset of European pedagogy were times when the word "school" meant "school generosity" (Kultaieva, 2016a, p. 104-105). Nobility is born, formed, developed in the actions of the individual, because the display requires no external dignity, and spiritual and emotional presence in human behavior.

Self-realization of a person in a positive mode of dignity does not occur automatically, but requires a painstaking work on himself. This affects both the average person and society as a whole. The latter involves the development of critical thinking, self-control and self-monitoring, which in turn requires the updating of teaching and educational practices, the democratization of education (Kultaieva, 2016b, p. 69). Therefore, the important task of educational work at a pedagogical university is to educate the dignity of the student and the future teacher in measuring positive liberty. Responsibility in all its dimensions is a manifestation of such dignity.

The professionalism of a modern teacher is formed through pedagogical communication. To provide the optimal process of professional development and development of students of the University of Pedagogy, including their social position, enables pedagogically appropriately organized educational environment of the higher educational institution, which is considered as a set of material and spiritual conditions, factors, relations established in the institution, to a certain extent affect the formation of a person, its development, education, socialization as a person, contribute to a common solution of problems and complicity in the activity, the potential subjects of pedagogical process and creative individuality (Kalashnikova, 2014). The peculiarities of pedagogical communication are determined by objectives priority: improvement of future teachers training, the development of personal and professional characteristics of each student, the disclosure of talents and abilities, spiritual and intellectual potential of the individual. 
Identifying personal point of view, fair and objective expression of his relation to the phenomena and events surrounding the validity is hindered by the incorrectly organized subject-subjective interaction of teachers and students during the training sessions and in the process of non-auditing educational activities. In this regard, one of the most important tasks of educational work with students at the Pedagogical University is the creation of a favorable psychological and pedagogical atmosphere during the training sessions and in the process of extracurricular educational activities for the development of critical thinking and the identification of students' attitudes to events and facts in the state and the world, social life, to other people, to their own "I" as evaluative judgments. The spiritual atmosphere necessary for pedagogical inspiration and pedagogical creativity is created in the university community, which is not just a collective, but above all a living social organism, where care for oneself is combined with the care of the fate of the nation (Trotsko, 2014, p. 9).

Freedom and democracy create framework conditions for the modernization transformations of university and social life. The task of strengthening Ukrainian statehood is to actualize the problem of modernization transformations of political education. Drain most of the talented young people to the West, not returning home after promising professionals trained in universities in Europe, we must consider the criteria odnim low efficiency of existing strategies for political education. Upbringing in the spirit of peace, the relationship between moral and legal education must become important components of political didactics. Formed future teacher citizenship is defined by his social and political maturity, it affects the level of national consciousness and patriotism, provides mastering basic cultural values and norms of a democratic society, mastering instrumentariyem for analyzing and making responsible decisions in specific life and professional situations.

In today's society, teachers have the role of agents of structuring social space. For the successful formation of social responsibility of future teachers, students need to be aware of the social role of their pedagogical profession. In the future teacher it is worthwhile to form the installation for implementation in the professional activity of social functions that today, due to objective reasons, has become much more complicated: child protection, comprehensive assistance in all spheres of its life, its involvement in the system of social relations, interaction with different educational institutions in order to create the optimal conditions for the development of the individual, the formation of his individuality, ensuring his socialization.

Today, students of pedagogical universities, remaining Ukrainian citizens and native speakers of national Ukrainian culture, simultaneously become representatives of all mankind. Post-conventional patriotism in a global society is no longer merely a cultural characteristic of a person and a citizen, but also a moral imperative, a person's responsibility. Moral values and meanings are only included in the general structure of the personality, reflecting her civic position, when they pass through the sphere of her feelings and experiences, transforming into beliefs, and ending up in practice in various kinds of activities, that is, when a person is not only an observer, but also participant in events or processes. The experience of educational work at the pedagogical university makes it possible to argue that the involvement of students in practical activities forms team-work skills, promotes the development of informed practical skills and actions, the acquisition 
of the necessary experience of social and pedagogical activities. It is in active work that the future teacher can express a true position, realize it in concrete actions and actions. Pedagogy of cooperation sets the model of an anti-authoritarian educational community capable of teamwork. To form the habit of the teacher, students should be involved in various types of social activities (self-government, volunteer work, execution of public tasks, etc.).

Powerful potential for solving the problems of upbringing moral qualities of teachers is student self-government, since pedagogically expedient its organization promotes the development of skills to manage, organize, formation of such qualities of personality, as the ability to self-knowledge, self-development, self-education, self-improvement (Honcharov, 2013, p. 5). In Kharkiv National Pedagogical University named after. G. S. Skovoroda has 5 student unions (the Union of Students and Youth, the Orthodox Union, the Union of Students of Chornobyl, the Union of Law Students, the Primary Trade Union Students Organization), creative groups, studios, clubs of interest. University students take an active part in environmental projects, animal protection programs; Volunteer unit of the "Zlagoda" University unites about 1,5 thousand students. Participation in the various types of student self-government, in which organically merging into a single whole the pedagogical leadership of the mentor and the independent activity of the student, the student group, involves the development and improvement of the educational activities of the future teacher (especially its organizational and communicative components), the formation of the readiness of the student for independent pedagogical activity, his initiative and social responsibility.

\section{CONCLUSIONS}

Consequently, in the post-industrial contexts of the knowledge society, the pedagogical university as a leading social institution is one of the factors that not only prompts the society for self-development, but also helps individuals and societies to promote control and self-control of modern social processes.

\section{REFERENCES}

Honcharov, D. O. (2013). Vykhovna robota u pedahohichnomu VNZ yak skladnyk profesiinoi pidhotovky maibutnoho vchytelia [Educational work at a pedagogical university as a component of the future teacher's professional training]. Humanizatsiia navchalno-vykhovnoho protsesu : zb. nauk. prats. Sloviansk, Ukraine: DDPU. Vyp. LXI, 83-89.

Kalashnikova, L. Yu. (2014). Umovy formuvannia sotsialnoi pozytsii studenta [Conditions for forming a student's social position]. Pedahohika ta psykholohiia: zb. nauk. prats. Kharkiv, Ukraine: KhNPU imeni H.S. Skovorody. Vyp. 45, 125-134.

Kultaieva, M. (2016). Pedahohichna provintsiia Petera Sloterdaika: revoliutsii na prykordonni [Pedagogical province of Peter Sloterdijka: Revolutions at the border]. Filosofska dumka, 2, 94-112.

Kultaieva, M. D. (2005). Moralni smysly idei universytetu u konteksti dosvidu pereotsinky "usikh kolyshnikh tsinnostei" [The moral meaning of the ideas 
of the university in the context of the experience of reassessing "all former values”]. Poklykannia universytetu: zb. nauk. prats. Kyiv, Ukraine: RIA "YaNKO", "VESELKA", 47-55.

Kultaieva, M. D. (2016). Myr i viina u realiiakh multykulturalizmu: osvitnii vymir [World and War in the Realities of Multiculturalism: Educational Dimension]. Visnyk KhNPU im. H. S. Skovorody "Filosofiia", 47 (P. II), 67-74.

Prokopenko, I. F. (2014). H. S. Skovoroda i skovorodynivtsi [Skovoroda and "skovorodynivtsi"]. In "Osvita i dolya natsiyi”: I. Kant ta H. Skovoroda: uyavnyy dialoh u suchasnykh sotsiokul'turnykh kontekstakh ["Education and the Fate of the Nation”: I. Kant and G. Skovoroda: An Imaginary Dialogue in Contemporary Socio-Cultural Contexts]: Procedings of International Conference, 4-6 (ukr).

Prokopenko, I. F. (2003). Peredmova [Preface]. In Kozats'ka hramota (naukovometodolohichne vprovadzhennya idey kozats'koyi pedahohiky u suchasnu pedahohichnu praktyku [Cossack charter (scientific and methodological introduction of the ideas of Cossack pedagogy to modern pedagogical practice]. H. Ye. Hrebenyuk (Ed.). Kharkiv: Styl'Izdat, 89.

Trotsko, H. (2014). Filosofiia H. S. Skovorody yak dzherelo pedahohichnoho natkhnennia [G. S. Skovoroda philosophy as a source of pedagogical inspiration]. In "Osvita $i$ dolya natsiyi": I. Kant ta H. Skovoroda: uyavnyy dialoh u suchasnykh sotsiokul'turnykh kontekstakh ["Education and the Fate of the Nation": I. Kant and G. Skovoroda: An Imaginary Dialogue in Contemporary Socio-Cultural Contexts]: Procedings of International Conference, 6-9. 